\title{
ДОСЛІДЖЕННЯ ТА АНАЛІЗ ПАРАМЕТРІВ ПРОДУКТИВНОСТІ ПРЕС-ФОРМИ
}

Розглянуто технологію виготовлення виробів із пластмас методом лиття під тиском. Представлено основні аспекти проектування ливарної багатогніздної прес-форми. Окрім цього, наведено математичні залежності для визначення оптимального числа гнізд у прес-формі. Спроектовано восьмигніздову прес-форму, на базі якої проведено дослідження. За результатами досліджень здійснено комплексний аналіз параметрів, які забезпечують раціональний вибір прес-форми 3 метою збільшення іiі продуктивності. Забезпечення потрібної кількості гнізд дає змогу значно зменшити економічні затрати. Особливу увагу приділено дослідженню впливу на оптимальну кількість гнізд у формі таких параметрів, як: об'єм впорскування, густина матеріалу, зусилля змикання форми і пластикаційна продуктивність вибраної ливарної машини. У середовищі Маthсаd побудовано графічні залежності зміни кількості гнізд у прес-формі від маси виробу, від площі проекції одного виробу в плані, від часу на закривання і відкривання форми та від часу витримки у формі, а далі, на базі цих досліджень, зроблено комплексний аналіз оптимального розрахунку кількості гнізд прес-форми. Встановлено, що на продуктивність прес-форми істотно впливає раціональний вибір оптимального числа гнізд прес-форми. Доцільність прийнятих рішень перевірено та впроваджено під час проектування технологічного оснащення на заводі "Полімер-Електрон" ДП ПАТ "Концерн-Електрон" за час стажування авторів дослідження на цьому підприємстві.

Ключові слова: прес-форма; гніздо форми; лиття під тиском; термопластавтомат.

Вступ. Одним із найпоширеніших процесів перероблення термопластичних полімерів у деталі є лиття під тиском. Цей метод забезпечує виготовлення якісних $\mathrm{i}$ високоточних виробів складної конфігурації без додаткового механічного оброблення, що забезпечує невеликі затрати енергетичних і трудових ресурсів, а також дає змогу скоротити тривалість виробничого процесу. Зазвичай лиття під тиском використовують для серійного або масового виробництва. Головним технологічним оснащенням при цьому є прес-форма. Проектування прес-форм - це складний процес, тому конструктор повинен мати високу кваліфікацію. Необхідно дотримуватись певних правил під час проектування. Однак $€$ недостатні умови для забезпечення високої якості виробу. Значну роль відіграє глибоке знання процесів, які відбуваються у ливарній машині - термопластавтомати. Високопродуктивний технологічний процес - це узгоджена робота термопластавтомата і прес-форми. Кожна прес-форма потребує від конструктора прийняття індивідуальних рішень, у цьому і проявляється фаховість конструктора. Тому значну увагу необхідно приділяти процесу конструювання форм, адже конструкторськотехнологічні помилки, зроблені на етапі проектування прес-форм, переважно виявляються після їх виготовлення під час випробовувань прес-форми і призводять до додаткових витрат на їх виправлення.

Постановка проблеми. Вирішальний вплив на економічні затрати процесу виробництва деталей з пластмас та збільшення продуктивності має питання вибору оптимальної конструкції прес-форми. Важливим чинником при цьому є правильний підхід у виборі кількості гнізд прес-форми.

Під час конструювання прес-форм важливе значення має комплексне дослідження всіх параметрів, які впливають на кількість гнізд, оскільки дослідження кожного чинника окремо не дасть змогу отримати оптимальну конструкцію прес-форми.

Аналіз останніх досліджень і публікацій. Проблему дослідження параметрів оснащення та оптимізації іiі параметрів представлена у працях (Velyka et al., 2010; Velyka \& Liaskovska, 2012; Boiko et al., 2016). Зокрема в роботі (Velyka et al., 2010) розроблено алгоритм розрахунку прямокутної матриці прес-форми на міцність і жорсткість та проведено дослідження, що стосуються оптимального вибору геометричних параметрів пресформи, які б забезпечували ії працездатність. Роботи (Velyka \& Liaskovska, 2012; Boiko et al., 2016) стосуються питанню оптимізації параметрів матриці вирубного штампу.

Метою роботи є дослідження та комплексний ана-

Інформація про авторів:

Бойко Михайло Васильович, ст. викладач, кафедра проектування та експлуатації машин. Email: osnastka@ukr.net

Велика Оксана Тарасівна, канд. техн. наук, доцент, кафедра проектування та експлуатації машин. Email: veloks@ukr.net

Лясковська Соломія Євгенівна, канд. техн. наук, доцент, кафедра проектування та експлуатації машин.

Email: solomiam@gmail.com; https://orcid.org/0000-0002-0822-0951

Великий Нестор-Тарас Ігорович, магістрант, кафедра проектування та експлуатації машин. Email: veloks@ukr.net

Цитування за ДСТУ: Бойко М. В., Велика О. Т., Лясковська С. Є., Великий Н.-Т. І. Дослідження та аналіз параметрів продуктивності прес-форми. Науковий вісник НлтУ України. 2019, т. 29, № 7. С. 129-133.

Citation APA: Boyko, M. V., Velyka, O. T., Liaskovska, S. E., \& Velykiy, N.-T. I. (2019). Study and Analysis of Press-Forms Productivity. Scientific Bulletin of UNFU, 29(7), 129-133. https://doi.org/10.15421/40290726 
ліз параметрів, які впливають на правильний вибір числа гнізд у прес-формі з метою збільшення її продуктивності, а також оптимізації економічних затрат.

Викладення основного матеріалу дослідження. Лиття під тиском - це процес виробництва деталей, який відбувається на спеціальних машинах - термопластавтоматах (ТПА). Гранули полімеру завантажуються у бункер ТПА, де захоплюються шнеком і переміщаються уздовж його осі до соплової частини. Паралельно 3 цим матеріал підігрівається та переходить 3 твердого стану у стан розплаву. Далі розплав під тиском 60260 МПа потрапляє у зімкнуту ливарну прес-форму та охолоджується. Після цього форма розкривається та дістається готовий виріб.

Після лиття реактопластів матеріал, що затвердів у ливникових каналах, не можна використовувати для вторинної переробки так, як під час лиття термопластів. Тому, вибираючи конструкції форми, потрібно враховувати відношення маси відходів у вигляді ливників і загальної маси деталей, що формуються. Це відношення $є$ оптимальним під час виготовлення масивних виробів. Однак навіть за неоптимального відношення (наприклад, для деталей з багатьма отворами) виготовлення деталей литтям під тиском є більш економічно вигідно, ніж пресування.

У ливарних формах нагрівальні елементи і термодавачі повинні бути розташовані так, щоб створювалося рівномірне температурне поле і точно контролювалася температура рухомої і нерухомої частин прес-форми.

Прес-форма для лиття під тиском - це спеціальна форма, яку представлено у вигляді набору пуансонів, матриць, ливникової системи, системи виштовхування виробів та допоміжних систем.

Вона складається 3 двох частин (рухомої і нерухомої), що контактують між собою по площині роз'єму форми. Суміщення нерухомої і рухомої частин форми здійснюється колонками і втулками.

Встановивши форму на ТПА, взаємна фіксація на співвісність ливникової втулки і сопла ТПА досягається за допомогою фланця. Нерухома і рухома частини монтуються відповідно на нерухому і рухому плити ТПА і закріплюються до них болтами. Формування виробу здійснюється в закритому положенні форми. Матеріал через центральний ливник (ливникову втулку), розподільні та впускні канали потрапляе в порожнину форми, де формується виріб. Для видалення з форми відлитого виробу призначено систему виштовхування. У процесі розмикання форми рухома частина форми переміщається вліво від площини роз'єму за допомогою приводу ТПА. Механізм виштовхування хвостовиком впирається у центральний упор ТПА і зупиняється, відбувається виштовхування виробів і ливникової системи 3 рухомої матриці. Під час змикання форми система виштовхування повертається у початкове положення завдяки контрвиштовхувачам.

Нерухома частина прес-форми складається 3 нерухомої основи, нерухомої матриці, ливникової втулки, фланця, центрувальних колонок, штифтів, вантажного болта, болтів і гвинтів. В окремих випадках, якщо в нерухомій матриці є формуючі знаки і вставки і нерухома основа виготовлена із сталі 3, рекомендуємо ставити між основою і нерухомою матрицею пластину.

Рухома частина форми складається з рухомої основи, плити притискної, плити знакотримачів, матриці ру- хомої, плити знімання, системи виштовхування, фланця, хвостовика, втулок центрувальних, штифтів, вантажного болта, болтів і гвинтів. Конструкцію рухомої частини прес-форми визначає система виштовхування, тобто спосіб знімання виробу з форми. Найбільш розповсюджені конструкції системи виштовхування це: знімання штовхачами; знімання плитою; знімання комбіноване.

Найвагомішим етапом виготовлення прес-форм є іï проектування. Проектування ливарної форми варто починати 3 визначення числа гнізд ливарної форми (рис. 1).
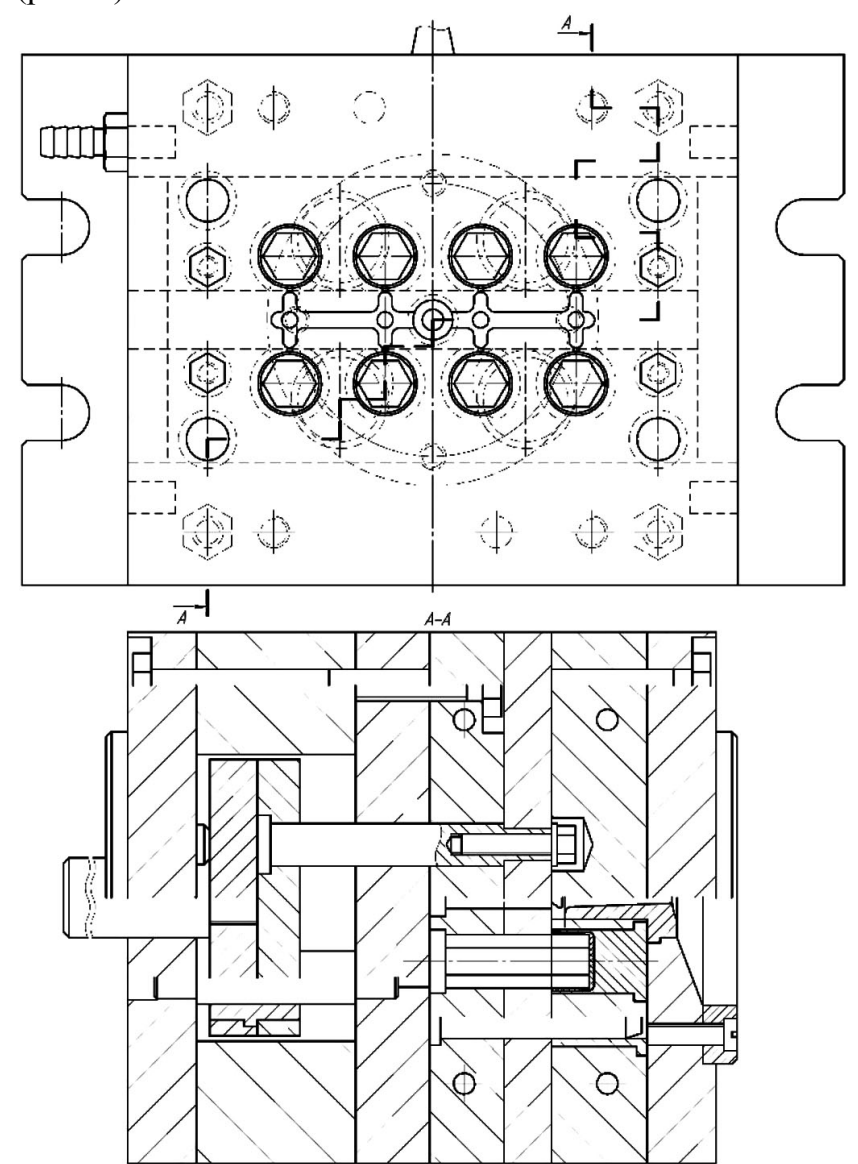

Рис. 1. Загальний вигляд спроектованої багатогніздової пресформи

Гніздо - це деталь формотворної порожнини, завдяки якій здійснюється відлив однієї деталі. Внаслідок виходить, що за один цикл можна створити відразу кілька елементів. Кількість гнізд у формі визначаємо залежно від складності виробу, його габаритів. За кількістю гнізд усі прес-форми можна поділити на одномісні та багатомісні. У прес-формах для невеликих виробів кількість гнізд досягає 50 і більше. Такі прес-форми хоча складні й дорогі, але дуже продуктивні. Досліджуючи та аналізуючи доцільність виготовлення складних та дорогих багатогніздових прес-форм, зазвичай враховують собівартість виливків, які можна отримати за термін експлуатації прес-форми.

Для багатосерійного, а особливо для масового виробництва малогабаритних елементів, такі багатогніздові прес-форми є економічно вигіднішими щодо собівартості, ніж декілька дешевших одногніздових пресформ, оскільки при цьому в кілька разів підвищується продуктивність прес-форми за їі невеликого збільшення в ціні. 
Важливим етапом $є$ також визначення зусилля змикання форми і часу одного циклу. Для цього потрібно ретельно продумати форму деталі, що виготовляється, i створити такі умови, внаслідок яких матеріал заповнить всю формоутворювальну порожнину за найкоротший час.

Розрахунок кількості гнізд у формах для прес-лиття має особливості. Наприклад, у знімних формах із горизонтальною площиною роз'єму кількість гнізд визначають, враховуючи величину площі проекції ливникової камери на площину роз'єму. Цю величину вважають вихідною, тому що вона залежить від необхідного питомого тиску пресування і робочого зусилля преса. Розігрітий прес-матеріал під тиском має пружні властивості, завдяки яким він здатний, майже без зміни і в усіх напрямках, передавати тиск на формуючі поверхні матриці. Тому в процесі роботи у формі виникають різноспрямовані зусилля.

На визначення оптимальної кількості гнізд у формі впливають такі параметри: об'єм впорскування, густина матеріалу, зусилля змикання форми i пластикаційна продуктивність вибраної ливарної машини.

Під час розрахунку кількості гнізд у формі за об'ємом впорскування ливарної машини маємо:

$$
N_{1}=\frac{\rho V}{m K_{1} K_{2}},
$$

де: $\rho$ - густина пластикаційного матеріалу; $V$ - максимальний об'єм набраної дози для впорскування; $m$ - маса виробу; $K_{1}$ - коефіцієнт, що враховує масу ливникової системи (зазвичай $\left.K_{1}=1,05 \ldots 1,15\right) ; K_{2}$ - коефіцієнт, що враховує зворотні витоки матеріалу в інжекційному циліндрі під час впорскування (практично можна прийняти $K_{2}=1,15 \ldots 1,25$ для ливарних машин без зворотного клапана на шнеку).

Кількість гнізд у формі щодо зусилля змикання машини:

$$
N_{2}=\frac{F}{s p_{\phi} K_{3} K_{4}},
$$

де: $F$ - зусилля змикання форми (за технічною характеристикою обладнання); $s$ - площа проекції одного виробу в плані; $p_{\phi}-$ тиск у формі (для ливарних марок реактопластів приймають $p_{\phi}=10 \ldots 30 \mathrm{MПа);} K_{3}-$ коефіцієнт, що враховує площу ливникової системи (у плані); $K_{4}$ - коефіцієнт, що враховує втрати тиску пресової частини ливарної машини і похибки виготовлення площин змикання півформ (приймають $K_{4}=1,2$ ).

Кількість гнізд $N_{3}$ у формі під час розрахунку щодо пластикаційної продуктивності матеріального циліндра вибраної моделі ливарної машини:

$$
N_{3}=\frac{\frac{1,1 q_{n л}}{p \tau_{\text {вum }}+\tau_{3}}}{m K_{1} K_{2}}=\frac{1,1 q_{n л}}{\left(p \tau_{\text {вит }}+\tau_{3}\right) \cdot m K_{1} K_{2}},
$$

де: $q_{n л}-$ пластикаційна продуктивність машини; $\tau_{\text {вит }}-$ час витримки виробу у формі; $\tau_{3}-$ час на закривання i відкривання форми.

Прес-форми для лиття під тиском виготовляються зі спеціальних марок сталей, що витримують вплив високих температур, механічних зусиль (рис. 2,a). Питання вибору типу прес-форми тісно пов'язане 3 характером виробництва (масове, серійне, дослідне).

На якість відлитих деталей і умови експлуатації форми значно впливає розташування гнізд. Вибираючи розташування гнізд, необхідно врахувати таке: повер- хню деталі найбільшої площі рекомендуємо розташовувати паралельно площині роз'єму для забезпечення надійності виштовхування деталей; довжина шляху течії матеріалу від ливникової втулки до порожнини, що оформляється, повинна бути мінімальною; виливка повинна залишатися на рухомій частині півформи (досягають виконанням зворотних ухилів, оформленням внутрішніх порожнин деталі знаками, що закріплені в рухомій частині форми тощо); мають бути забезпечені надійність установки і фіксації арматури і зручність виштовхування готової деталі; місця підведення впускного ливника необхідно вибрати з урахуванням не тільки умов заповнення форми, а й легкості подальшого видалення ливника (рис. 2,б).
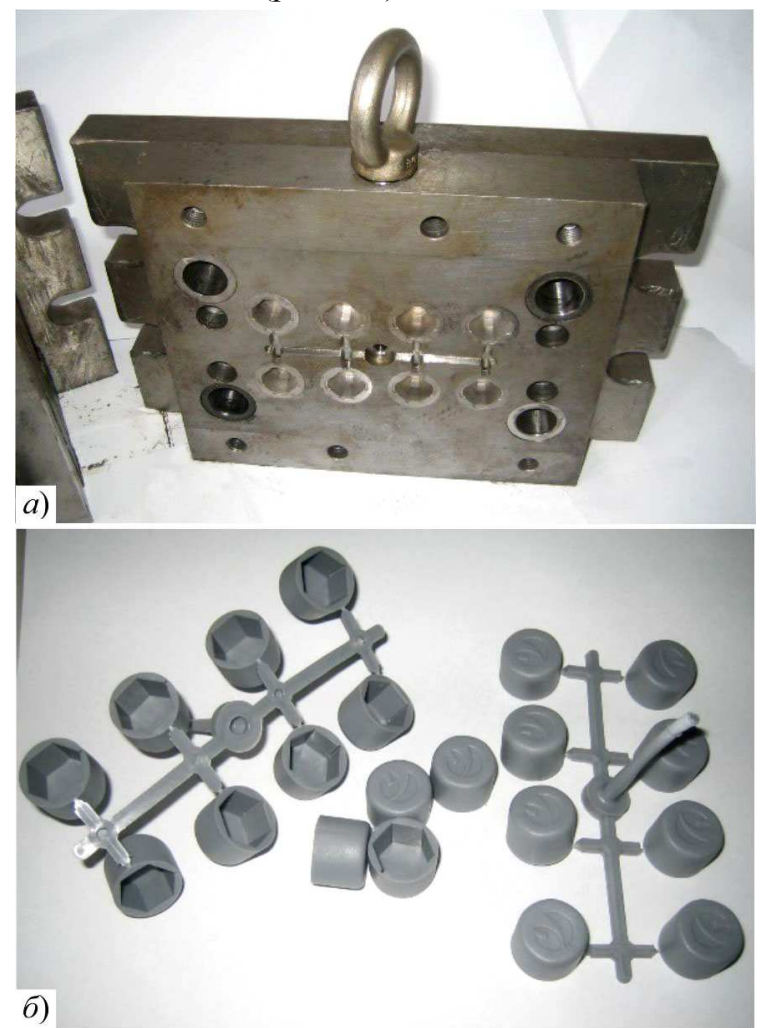

Рис. 2. Досліджувана багатогніздова прес-форма в металі (а); деталі $з$ ливниковою системою, отримані 3 досліджуваної пресформи (б)

Для дослідження застосували систему автоматизованого проектування Mathcad. Внаслідок проведення досліджень отримали графічні залежності зміни кількості гнізд у прес-формі від маси виробу, від площі проекції одного виробу в плані, від часу на закривання і відкривання форми та від часу витримки у формі. На підставі цих досліджень зробили аналіз зміни потрібної кількості гнізд у формі для лиття пластмасових деталей під тиском від максимального об'єму набраної дози для впорскування, від зусилля змикання форми та від пластикаційної продуктивності машини.

3 отриманої графічної залежності (рис. 3,a) випливає, що кількість гнізд у формі нелінійно залежить від маси майбутнього виробу. Із зростанням маси виробу кількість гнізд зменшується. Так, наприклад, із зростанням маси виробу від 0,058 до 0,114 кг - приблизно в два рази (за максимального об'єму набраної дози для впорскування - $300 \mathrm{~cm}^{3}$ ) - кількість гнізд зменшується від 4 до 2 - теж у два рази. Також із цього графіка випливає, що кількість гнізд у формі залежить від максимального об'єму набраної дози для впорскування. Із зростан- 
ням дози - кількість гнізд теж збільшується. Так, наприклад, для орієнтовної маси майбутнього виробу 0,076 кг із збільшенням максимального об'єму набраної дози для впорскування від 100 до $300 \mathrm{~cm}^{3}$ - кількість необхідних гнізд у прес-формі для виготовлення цього виробу зростає теж від 1 до 3 - тобто в три рази.

Графічні залежності на рис. 3,6 дають змогу зробити висновок, що кількість гнізд у формі нелінійно залежить від площі проекції одного виробу в плані. Із зростанням площі проекції виробу в плані кількість гнізд зменшується. Так, наприклад, із зростанням площі проекції виробу в плані від 7 до $14 \mathrm{~cm}^{2}-$ приблизно в два рази (за зусилля змикання форми - 100 т) - кількість гнізд зменшується від 2 до 1 - теж приблизно у два рази. Також на цій графічній залежності можна побачити, що кількість гнізд у формі залежить від зусилля змикання форми. Із зростанням зусилля змикання форми кількість гнізд теж зростає. Так, наприклад, для площі проекції в плані майбутнього виробу $8 \mathrm{~cm}^{2}$ із збільшенням зусилля змикання форми від 100 до 150 т - кількість необхідних гнізд у прес-формі для виготовлення цього виробу приблизно зростає від 2 до 3 - тобто у півтора раза.
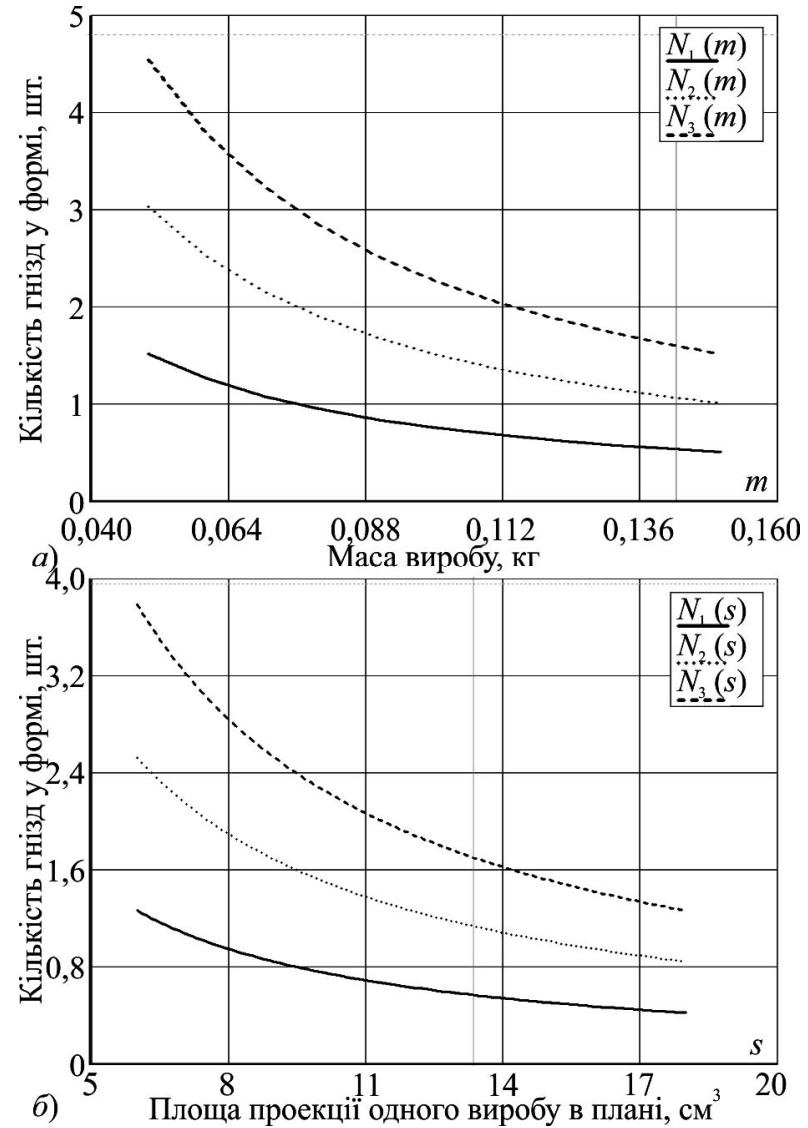

Рис. 3. Графік залежності кількості гнізд у прес-формі від: a) маси виробу: $N_{1}(m)$-максимальний об'єм набраної дози для впорскування - $100 \mathrm{~cm}^{3} ; N_{2}(m)$ - максимальний об'єм набраної дози для впорскування $-200 \mathrm{~cm}^{3} ; N_{3}(m)$ - максимальний об'єм набраної дози для впорскування - $300 \mathrm{~cm}^{3}$; б) площі проекції одного виробу в плані: $N_{1}(s)$ - зусилля змикання форми - $50 \mathrm{~T}$; $N_{2}(s)$ - зусилля змикання форми - $100 \mathrm{~T} ; N_{3}(s)$ - зусилля змикання форми - 150 т

Із залежності (рис. 4,a) випливає, що кількість гнізд у формі нелінійно залежить від часу витримки виробу у формі. Із зменшенням часу витримки виробу кількість гнізд збільшується. Так, наприклад, із зменшенням часу витримки виробу приблизно від 15 до 7 с (за маси виро- бу - 0,05 кг) кількість гнізд збільшується від 1 до 2. 3 цього ж графіка бачимо, що кількість гнізд у формі залежить від маси виробу. Із зменшенням маси - кількість гнізд збільшується. Так, наприклад, для приблизного часу витримки виробу 5 с із зменшенням маси від 0,15 до 0,05 кг - кількість необхідних гнізд у прес-формі для виготовлення цього виробу збільшується від 1 до 3.

3 отриманої графічної залежності (рис. 4,б) випливає, що кількість гнізд у формі нелінійно залежить від часу на закривання і відкривання форми. Із зменшенням часу на закривання і відкривання форми кількість гнізд збільшується. Так, наприклад, із зменшенням часу на відкривання і закривання форми приблизно від 4 до 2 с (за пластикаційної продуктивності машини - 6 см$^{3}$ ) кількість гнізд збільшується від 4 до 5.
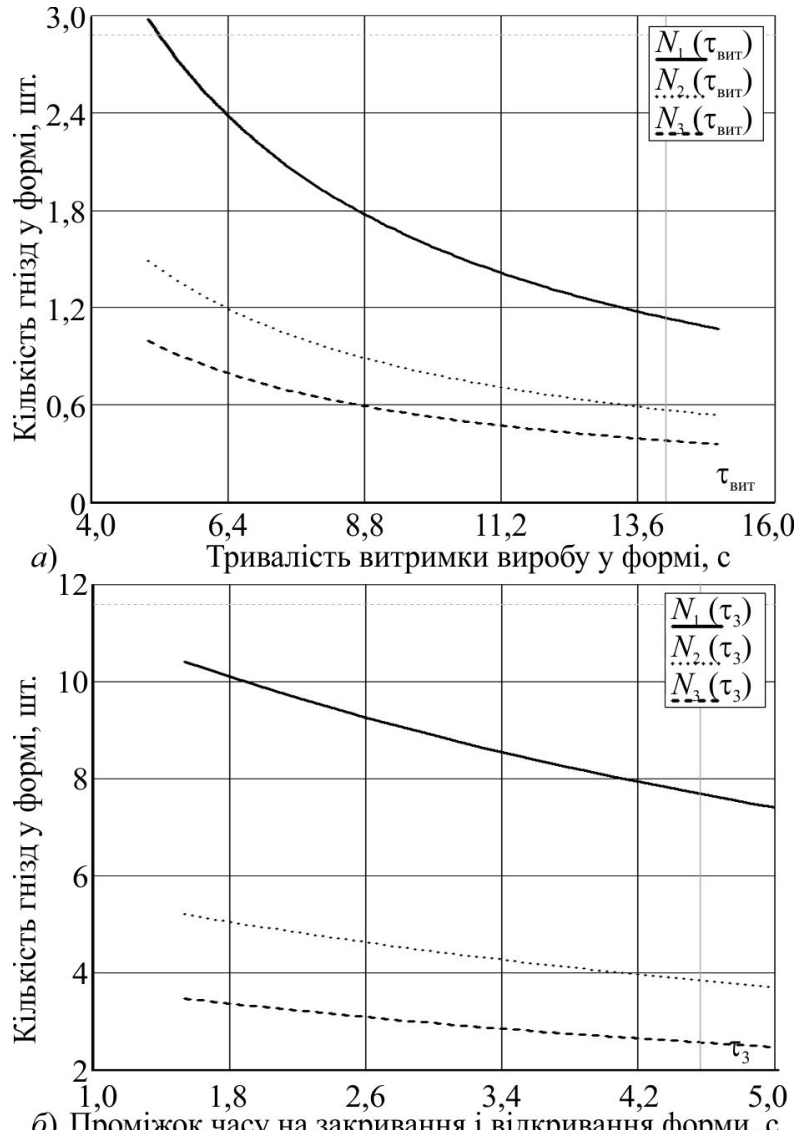

б) Проміжок часу на закривання і відкривання форми, с

Рис. 4. Графік залежності кількості гнізд у прес-формі від: а) тривалості витримки виробу у формі: $N_{1}\left(\tau_{\text {вит }}\right)$ - маса виробу 0,05 кг; $N_{2}\left(\tau_{\text {вит }}\right)$ - маса виробу $-0,10$ кг; $N_{3}\left(\tau_{\text {вит }}\right)$ - маса виробу 0,15 кг; б) проміжку часу на закривання і відкривання форми: $N_{1}\left(\tau_{3}\right)$ - пластикаційна продуктивність машини $-4 \mathrm{~cm}^{3} ; N_{2}\left(\tau_{3}\right)-$ пластикаційна продуктивність машини $-6 \mathrm{~cm}^{3} ; N_{3}\left(\tau_{3}\right)$ - пластикаційна продуктивність машини $-8 \mathrm{~cm}^{3}$

Також із цього графіка випливає, що кількість гнізд у формі залежить від пластикаційної продуктивності машини. Із зменшенням пластикаційної продуктивності машини - кількість гнізд навпаки зростає. Так, наприклад, для приблизного часу на закривання і відкривання $4 \mathrm{c}$ із зменшенням пластикаційної продуктивності машини від 6 до 4 cм $^{3}$ - кількість необхідних гнізд у пресформі для виготовлення цього виробу збільшується від 4 до 8. Внаслідок комплексного підходу остаточно кількість гнізд визначають рівним найменшому з трьох отриманих значень $N$. 
Висновки. Проведено дослідження всіх параметрів, які впливають на кількість гнізд прес-форми.

Важливим етапом реалізації досліджень є проведення комплексного аналізу, що дає змогу оптимізувати іiі параметри та здійснити раціональний вибір кількості гнізд для забезпечення іiі працездатності та істотного зменшення економічних затрат.

Проведені дослідження використовували для проектування технологічного оснащення на заводі "ПолімерЕлектрон" ДП ПАТ "Концерн-Електрон" за час стажування авторів роботи на цьому підприємстві.

\section{Перелік використаних джерел}

Boiko, M. V., Velyka, O. T., Liaskovska, S. Ye., \& Velykyi, N.-T. I. (2016). Doslidzhennia ta optymizatsiia konstruktyvnykh parametriv matrytsi vyrubnoho shtampu. Scientific Bulletin of UNFU, 26(4), 255-260. [In Ukrainian].

Velyka, O. T., \& Liaskovska, S. Ye. (2012). Optymizatsiia heometrychnykh parametriv pid chas rozrakhunkiv detalei u seredovyshchi CAD/SAE AutoCADMechanical 2006. Optymizatsiia vyrobnychykh protsesiv $i$ tekhnichnyi kontrol u mashynobuduvanni ta pryladobuduvanni, 729, 80-85. Lviv: Lviv Polytechnic Publishing House. [In Ukrainian].

Velyka, O. T., Topilnytskyi, V. H., Boiko, M. V., \& Lampika, R. V. (2010). Rozrakhunok priamokutnoi matrytsi pres-formy na mitsnist i zhorstkist. Avtomatyzatsiia vyrobnychykh protsesiv $v$ mashynobuduvanni ta pryladobuduvanni, 44, 74-79. Lviv: Lviv Polytechnic Publishing House. [In Ukrainian].

M. V. Boyko, O. T. Velyka, S. E. Liaskovska, N.-T. I. Velykiy Lviv Polytechnic National University, Lviv, Ukraine

\section{STUDY AND ANALYSIS OF PRESS-FORMS PRODUCTIVITY}

The article presents the results of parameters research that affect press-form productivity. A press-form is the main technological equipment for manufacturing technology of plastic products by injection molding. Molding under pressure is a process of manufacturing parts, which occurs on special machines - thermoplastics machines. This method is one of the most common processes of processing thermoplastic polymers for a detail, which provides the production of high-quality and high-precision products of complex configuration without additional machining. The design of press-forms is a complex process and the most important stage in the manufacture. As a rule, it begins with determining the required number of nests. The main aspects of the design of the foundry press-forms are presented. In addition, the mathematical dependences for determining the optimal number of nests in the mold are given. The eight-pressure press-form was designed; on its basis the research was conducted. In particular, the influence on the optimal number of nests in the mold of the parameters such as the volume of injection, the material density, the closing force of the mold and the plasticization performance of the selected casting machine have been investigated. In the Mathcad environment, graphic dependencies of the number of nests in the die-form are plotted based on the weight of the product, from the projection area of one product in terms of the time from the closure and opening of the form, and the time of exposure to the forms. According to the results of the research, a comprehensive analysis of the parameters that ensure the rational choice of the press-form, and, consequently, affect the change in the required number of nests in the form of molding of plastic parts under pressure. This allowed making an optimal calculation of the number of press-form nests. The authors have established that the productivity of the press-form is significantly influenced by the rational choice of the optimal number of nests of the press-form. Providing the required number of nests can significantly reduce the economic costs. The appropriateness of the decisions was verified and implemented during the design of technological equipment at Polimer-Electron Ltd., as a part of the internship of the authors of the article at this enterprise.

Keywords: press-form; form socket; injection molding; thermoplastic machine. 